Novia Fetri Aliza

Fakultas A gama I slam U M Y

aliza@umy.ac.id

\title{
Pendampingan Remaja Melalui Empowering Community Psychology Untuk Meningkatkan Orientasi Masa Depan
}

\author{
https:/ / doi.org/ 10.18196/ bdr.6248
}

\begin{abstract}
The purpose of this program is to change the adolescent mindset as well as improve the future orientation of youth in education. Furthermore, the community is expected to have awareness to run its the role as a support system in improving the future orientation of adolescents. The method of implementation of this program is empowering community psychology approach implemented through several stages, namely providing group counseling and motivation to adolescents, counseling to improve the participation of parents and teachers in improving the future orientation of adolescents. Parents tales of psycho education about educating teenagers, the importance of continuing adolescent education and improving parental patterns of concern about adolescents who find it difficult to get a mate. To the group of teachers given counseling effective communication with adolescents. The result of this assistance is the emergence of awareness of students (adolescents) to continue education to a higher level such as high school or vocational school by $85 \%$ from the previous only $40 \%$, while those who have motivation to continue education to college increased $10 \%$ from $0 \%$. Teenagers are still worried about getting children's labels unsold by the public, but have started to decrease. Parents begin to have an awareness of the importance of their role in the future of their teenagers. Teachers gain insight and discover new methods of effective communication with adolescents.
\end{abstract}

Key word: Community Psychology, teens, Future Orientation

\section{PENDAHULUAN}

D esa N gloro Kabupaten G unungkidul, secara G eografis merupakan desa yang terletak cukup jauh dari pusat kota, dengan pekerjaan utama masyarakat adalah pertanian. Jarak tempuh yangjauh dari perkotaan ini menjadikan penduduk di desa $\mathrm{N}$ gloro membutuhkan usaha yanglebih besar untuk men dapatkan akses pen didikan. Sehingga faktor ini menjadi salah satu penyebab banyaknya remaja yang putus sekolah dan tidak melanjutkan pendidikan ke jenjang yang lebih tinggi. Rendahnya minat remaja untuk melanjutkan pendidikan ke jenjang yang lebih tinggi ini, juga disebabkan oleh faktor yang lain diantaranya konsep berfikir yang kurang tepat tentang hidup seperti ungkapan "sekolah 
itu untuk orang kaya", khawatir tidak mendapatkan jodoh terutama remaja putri sehingga memilih untuk menikah muda serta rendahnya dukungan dari lingkungan dan orangtua baik dukungan moril ataupun materil. Situasi seperti ini terus terjadi dari generasi ke generasi berikutnya, sehingga anak-anak yang di desa $\mathrm{N}$ gloro tumbuh dalam lingkungan yang memiliki pola berfikir yang sempit, daya juan g ren dah serta terbiasa men gharapkan datangnya bantuan dari wilayah perkotaan sehingga tidak memiliki pemahaman yang memadai tentang orientasi masa depan.

Chaplin (Palmer, 2010) menyebutkan bahwa orientasi masa depan merupakan persepsi terhadap pengalaman masa lalu yang dikaitkan dengan kondisi yang dialami pada masa sekarang dan masa mendatang, sehingga disebut juga sebagai fenomena kognitif motivasional yang cukup kompleks. Fenomena yang cukup kompleks ini perlu mendapatkan pendampingan untuk masyarakat desa $\mathrm{N}$ gloro khususnya remaja, karena remaja merupakan generasi yang akan mengubah dan memperbaiki kualitas hidup masyarakat desa $\mathrm{N}$ gloro di masa mendatang. Remaja yang memiliki pemahaman tentang orientasi masa depan akan mampu menyusun dan merencanakan kualitas kehidupan yang lebih baik di masa yang akan datang. H urlock (1998) menyebutkan bahwa orientasi masa depan adalah tahapan perkembangan yang harus dilewati pada masa remaja. Sehingga remaja sesungguhnya membutuhkan pendampingan dan arahan oleh orang dewasa dalam mempersiapkan diri dan merencanakan kehidupannya di masa mendatang.

E mpowering community psychology merupakan pendekatan yang dapat menyentuh semua lapisan masyarakat yang memiliki keterkaitan dengan orientasi masa depan remaja, sehingga dengan metode ini diharapkan dapat menguatkan faktor pendukung dan meminimalisir faktor pen ghambat. Remaja diharapkan memiliki orientasi masa depan dan memiliki motivasi yang selalu terjaga, artinya semangat remaja dalam menata dan merencanakan masa depannya tidak hanya bergelora sesaat melainkan dapat bertahan lebih lama karena semua elemen yang ada di tengah masyarakat telah berperan memberikan dukungan kepada remaja.

O leh karenaitu, program pengabdian ini dimaksudkan untuk meningkatkan orientasi masa depan remaja bidang pendidikan melalui emporing community psychology. adapun yang dimaksudkan dengan empowering community psychology ini adalah selain remaja yang menjadi target utama pen gabdian masyarakat ini, orang-orang yang berada disekitar remaja juga mendapatkan pendampingan seperti orangtua dan guru. Tujuannya adalah untuk mengubah mind set orang tua dan meningkatkan skill komunikasi efektif guru yang mendampingi kehidupan remaja. 


\section{9}

\section{METODE PELAKSANAAN}

Pelaksanaan pengabdian ini dilakukan dengan melibatkan sepuluh orang mahasiswa yang sedang melaksanakan program KKN yang bertugas melakukan penjajagan awal dan mempersiapkan kebutuhan teknis pelaksanaan program pengabdian. A dapun rancangan dalam program ini terdiri dari beberapa tahapan yaitu (1) melakukan assessment komunitas, tujuan dari dilakukannya assessment ini adalah untuk menentukan target perilaku yang paling utama dan segera untuk diberikan pendampingan; (2) konseling kelompok dan penyuluhan kepada remaja, tujuannya adalah memunculkan insight tentang masa depan dan memiliki motivasi dalam menggapai impian di masa yang akan datang; (3) psikoedukasi kepada orangtua, tujuannya adalah untuk memunculkan insight kepada orangtua tentang pentingnya peran orangtua dalam mendampingi dan memberikan dukungan dalam merencanakan masa depan remaja; (4) psikoedukasi kepada guru, tujuannya adalah untuk membantu guru untuk dapat meningkatkan keterampilan dalam berkomunikasi efektif dengan remaja.

\section{HASIL DAN PEMBAHASAN}

\section{PraProgram}

Pengabdian ini dimulai dengan melakukan assessment kepada beberapa kelompok masyarakat yaitu tokoh masyarakat, kelompok guru, kepala sekolah dan beberapa orang remaja. Assessment ini dilakukan dengan cara wawancara kelompok berdasarkan panduan wawancara kelompok yang telah dipersiapkan sebelumnya, tujuannya adalah untuk mengungkap aspek yang sama pada setiap kelompok. Respon dari setiap kelompok cukup positif dan bersedia memberikan dukungan untuk semua proses pen gabdian yang akan dilakukan.

Berdasarkan hasil assessment yang telah dilakukan ditemukan beberapa hal yang dibutuhkan oleh masyarakat, diantaranya adalah remaja yang kurang berminat melanjutkan pendidikannya ke jenjang yang lebih tinggi sehingga banyak yang putus sekolah dan menikah pada usia muda, rendahnya pengetahuan orangtua tentang mendidik anak sehingga menyebabkan rendahnya peran orangtua dalam memberikan dukungan terhadap pendidikan anaknya, serta rendahnya skill yang dimiliki oleh guru dalam berkomunikasi yang efektif dalam memberikan dorongan kepada anak didiknya.

\section{Pelaksanaan Program}

Berdasarkan hasil assessment yang telah dilakukan kepada masyarakat di desa $\mathrm{N}$ gloro 
dapat dilihat bahwa hal yang perlu didampingi dalam pengabdian ini adalah meningkatkan orientasi masa depan remaja melalui pendekatan empowering community psychology. G uru-guru yang berada di SM P muhammadiyah $\mathrm{N}$ gloro mengeluhkan kondisi sisiwanya yang masih sulit untuk didorong melanjutkan sekolah ke jenjang yang lebih tinggi, beberapa diantara siswanya putus sekolah pada jenjang kelas VII dan kelas VIII. 0 ran gtua tidak merasa sedih ataupun men gkhawatirkan masa depan anaknya yang putus sekolah, bahkan sebagian masyarakat masih meyakini bahwa sekolah bukanlah hal yang penting terutama untuk anak perempuan. Sehingga, pengabdian ini difokuskan pelaksanaannya memberikan pendampingan kepada remaja beserta orang-orang yang terlibat dalam keseharian remaja tersebut sehingga pola fikir atau mind set masyarakat di desa N gloro dapat berubah dan lebih berkembang.

Tahap pertama yang mendapatkan pendampingan dalam program pengabdian ini adalah remaja yang duduk di bangku sekolah menengah pertama. Adapun SM P M uhammadiyah $\mathrm{N}$ gloro adalah satau satunya SM P yang terdapat di desa $\mathrm{N}$ gloro, sehingga sekolah inilah yang menjadi pilihan untuk dilaksanakannya pengebdian ini. Seluruh siswa yang ada di SM P M uhammadiyah $\mathrm{N}$ gloro berjumlah lebih dari 200 orang, namun yang direkomendasikan oleh kepala sekolah dan guru untuk prioritas mendapatkan pendampingan adalah 30 orang siswa yang duduk di kelas VIII. Siswa ini terdiri kelompok yang cukup beresiko putus sekolah karena mengalami beberapa permasalahan dalam proses belajar mengajar di sekolah, belum memiliki cita-cita, beresiko menikah dini terutama siswa yang perempuan. Kemudian dilakukan assessment mendalam terhadap 30 orang siswa ini, ditemukan 12 orang yang sudah memiliki keinginan untuk melanjutkan pendidikan kejenjang SM A dan SM K atau sejumlah 40\%, sedangkan 50\% lagi tidak memiliki minat sama sekali untuk melanjutkan pendidikan sedangkan $10 \%$ menjawab masih tidak tau. M inat untuk melanjutkan ke perguruan tinggi masih beum ada satu orangpun siswa yang memikirkan hal itu.

Berdasarkan hasil dari assessment awal tersebut dilakukan konseling kelompok kepada remaja yan g berfokus pada orientasi masa depan bidang pendidikan, dengan teknik miracle question (mengarahkan pertanyaan untuk remaja mampu memunculkan imajinasinya hal apa yang akan terjadi sekiranya masalah yang dihadapinya selesai dengan ajaib)dan scallingquestion yaitu mengarahkan remaja untuk memberikan penilaian terhadap kondisi yang dialaminya baik itu masalah, harapan, perasaan pencapaian tujuan berdasarkan pemberian rating pada skala 1-9, kemudian remaja diberi pujian terhadap pencapaian positif dan kemajuan yang dialaminya. Pada sesi ke dua remaja diberikan penyuluhan 


\section{1}

tentang motivasi melanjutkan sekolah, dengan mengubah maind set kemudian memberikan resiko serta manfaat yang kemungkinan dihadapinya bila melanjutkan sekolah dan tidak melanjutkan sekolah. Selain itu remaja juga diberikan edukasi tentang pandangan Islam tentang jodoh serta bahaya menikah pada usia muda.

Konseling kelompok berfokus solusi ini dipandu oleh Psikolog yang sudah terbiasa melakukan konseling kepada remaja. Pada tahap awal proses konseling, semua siswa dibagi menjadi 3 kelompok, di mana setiap kelompok terdiri dari 10 orang yang didampingi oleh satu orang konselor dan satu orang ko konselor. Tugas konselor adalah memandu proses konseling sesuai dengan modul konseling yang telah dirancang sebelumnya, sedan gkan ko konselor bertugas sebagai observer dan menjadi notulen selama proses konseling berlangsung. A dapun proses konseling kelompok dapat dilihat dalam gambar 1 .

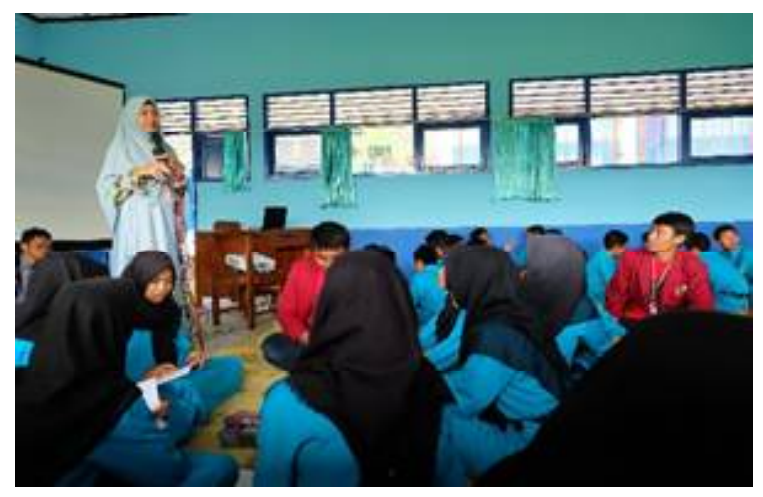

Gambar 1. Pelaksanaan konseling kelompok

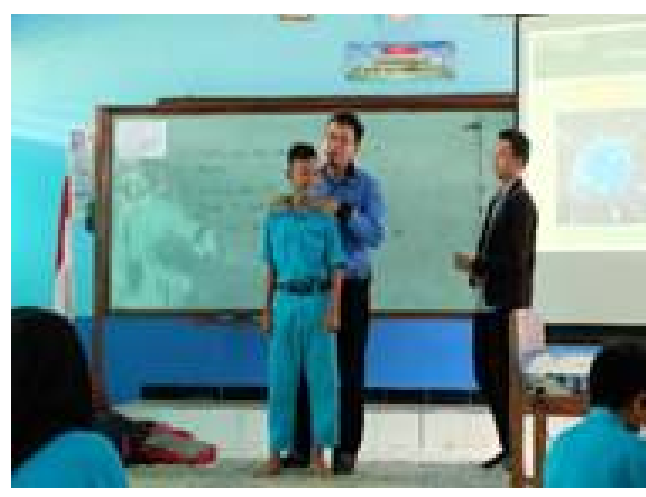

Gambar 2. Memberikan motivasi remaja di SMP Muhammadiyah Ngloro

Pada sesi ke dua semua peserta konseling di gabungkan menjadi kelompok besar, sehingga pada proses ini 30 orang peserta dikelompokkan menjadi satu kelompok. Beriktnya peserta diberikan penyuluhan dan motivasi tentang arti penting melanjutkan pendidikan, mengubah mind set tentang kekhawatiran tidak mendapatkan jodoh, serta memberikan edukasi tentang bahaya dan faktor resiko yang akan dihadapi oleh remaja bila menikah diusia muda. Pada proses ini dipandu oleh psikolog yang sudah terbiasa menjadi motivator remaja sehingga pada proses ini remaja terlihat antusias dan mampu mengikuti materi penyuluhan dengan baik. Proses penyuluhan dan pemberian motivasi yang diberikan kepada remaja di desa N gloro bisa dilihat pada Gambar 2. 


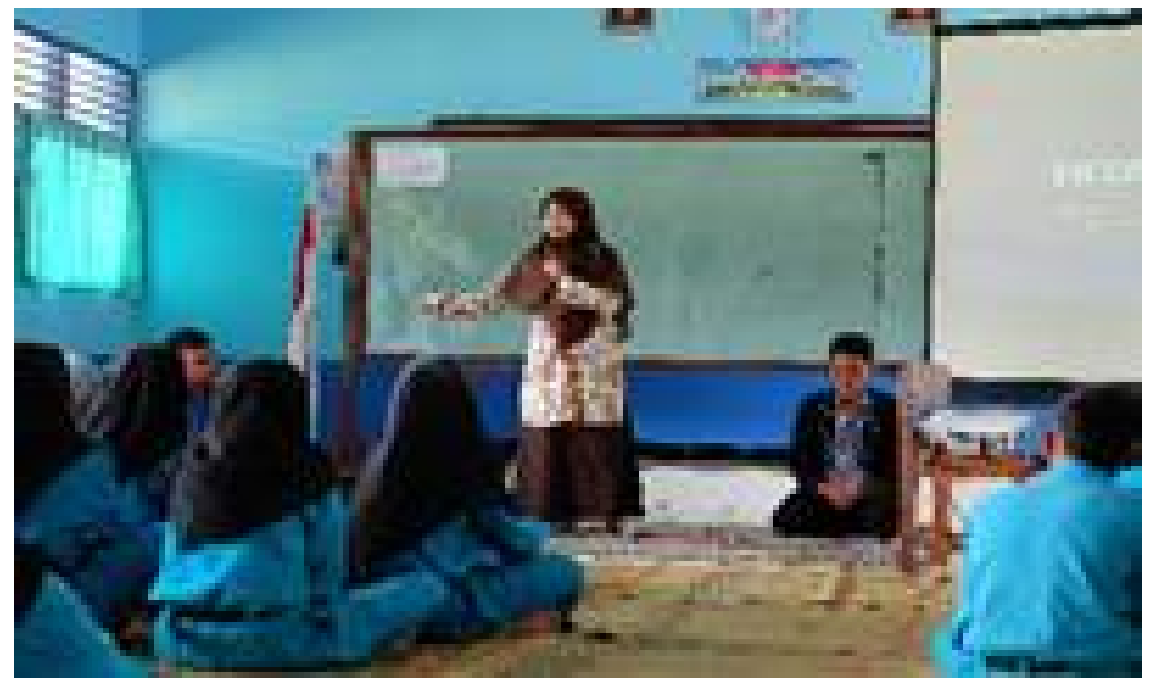

Gambar 3. Memberikan psikoedukasi tentang bahaya menikah muda

Pada sesi ketiga dalam tahap pen gabdian ini semua orangtua dari 30 orang siswa yang telah mendapatkan konseling kelompok diundang, kemudian diberikan penyuluhan tentang pentingnya pendidikan dan pentingnya peran orangtua dalam mendukung pendidikan remaja. Pada sesi ini dihadiri oleh 18 orangtua, karena pada waktu pelaksanaan program pengabdian ini berbarengan dengan musin panen petani, sehingga beberapa orangtua tidak dapat menghadiri undangan pelaksanaan pegabdian. M eskupun demikian, semua yang hadir terlihat antusias dan men gikuti proses penyuluhan hingga akhir.

Sesi terakhir dari proses pengabdian ini adalah mengundang guru untuk diberikan penyuluhan terkait peningkatan skill guru dalam komunikasi efektif dengan remaja. Guru yang hadir pada proses ini terdiri dari guru kelas yang berfungsi sekaligus sebagai guru konseling, guru agama serta guru bahasa inggris. Semua guru yang hadir juga mengikuti proses ini dengan antusias hingga selesai, dan diakhir sesi dalam program

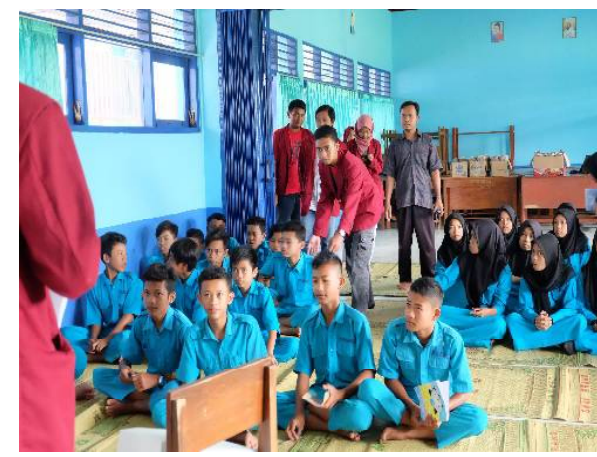

Gambar 3. Kondisi siswa pada saat pelaksanaan assessment awal kurang bersemangat

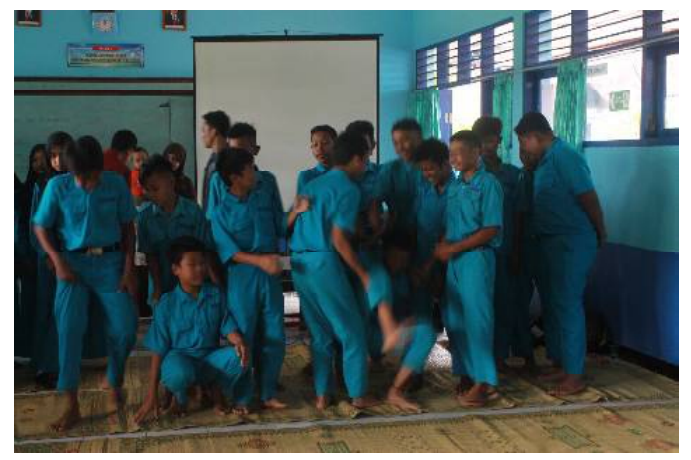

Gambar 4. Siswa mulai bersemangat setelah selesai program pengabdian 


\section{3}

pengabdian ini semua siswa yang ikut bersalaman dengan fasilitator, ko fasilitator serta diakhiri dengan berfoto bersama, dan siswa terlihat lebih bersemangat bila dibandingkan sebelum dilaksanakannya program pengabdian.

\section{Evaluasi}

Remaja putri mulai mendapatkan insight tentang kekeliruan pemikirannya mengenai jodoh, mereka juga sudah mulai meyakini bahwa tidak perlu malu bila diberi label perempuan tidak laku yang belum menikah pada usia muda. Remaja mulai terlihat bersemangat untuk melanjutkan sekolah ke jenjang yang lebih tinggi meskipun baru 85 $\%$ yang memiliki keinginan yang kuat untuk melannjutkan pendidikan ke jenjang yang lebih tinggi, sisanya sebanyak 15\% masih ragu-ragu. Sedangkan keinginan melanjutkan pendidikan ke jenjang perguruan tinggi baru $10 \%$ dari sebelumnya belum ada satu orangpun yang memikirkan tentang melanjutkan pendidikan keperguruan tinggi. Sehingga bila dilihat dalam diagram perubahan mind set sebelum dan setelah konseling pada remaja di desa $\mathrm{N}$ gloro bisa dilihat pada Gambar 5.
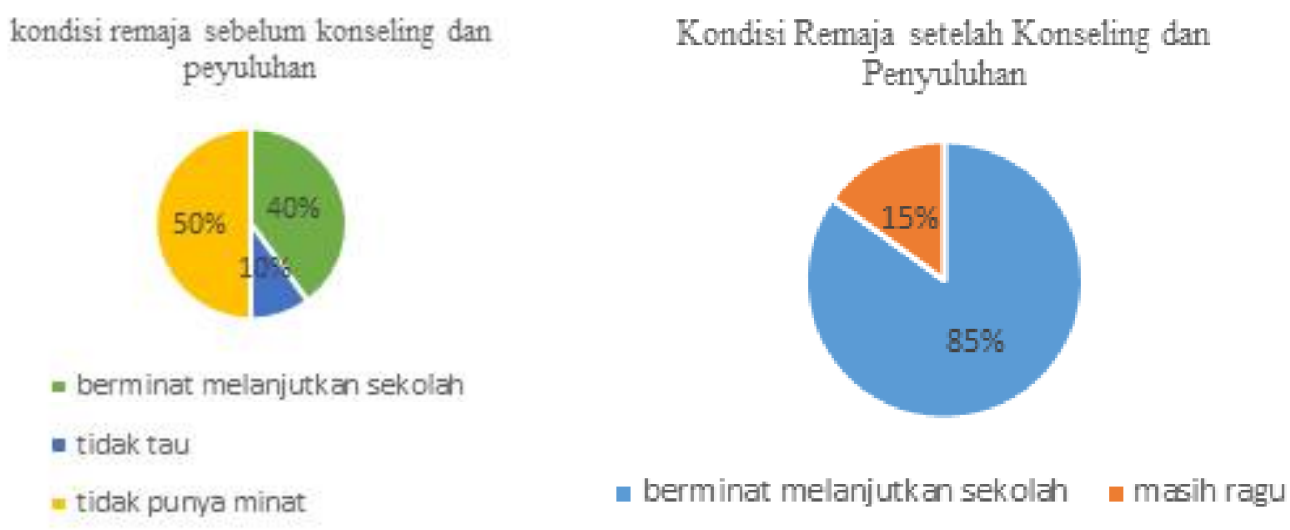

Gambar 5. Perbedaan OMD bidang pendidikan remaja sebelum dan setelah pendampingan

Konseling kelompok ini cukup berhasil memberikan perubahan mind set tentang orientasi masa depan bidang pendidikan yang dialami oleh remaja di D esa N gloro. Corey (2006) menyebutkan bahwa konseling kelompok dapat membantu seseorang memiliki pengalaman baru yanglebih kaya, sehingga individu tersebut memiliki kesempatan untuk belajar dan berfugsi secara aktif mengembangkan kapasitas yang dimilikinya untuk menyelesaikan permasalahan yang dihadapi seta mampu menemukan kepuasan dalam menjalani hidup berkelompok dengan orang lain.

0 'C onnel (2005) menyebutkan bahwa konseling kelompok berfokus solusi juga dapat membantu individu untuk menemukan petunjuk dalam menemui kelebihan kelebihan 
yang dimiliki sehingga kelebihan yang dimiliki dapat dimanfaatkan untuk mencapai tujuan yang diinginkan. M unculnya kesadaran dari diri remaja di desa $\mathrm{N}$ gloro tentang kelebihan yang ada dalam dirinya di tengah kesulitan yang ada merupakan cara yang dapat dimanfaatkan untuk memunculkan dorongan untuk terus membangun dan menggapai cita-citanya. Remaja juga sudah mulai mampu menilai dan membandingkan dirinya dengan orang lain yang berada jauh lebih sulit mendapatkan akses pen didikan.

0 rangtua dan beberapa orang tokoh masyarakat yang men dapatkan penyuluhan mulai menyadari tentang pentingnya peran mereka dalam memberikan dukungan kepada anak remajanya dalam merencanakan masa depan. Beberapa orangtua mengatakan bahwa mereka baru mengetahui meskipun anaknya sudah sekolah bukan berarti semua permasalahan mereka akan dibantu dan diselesaikan oleh guru di sekolah. Seperti uncapan seorang ibu paruh baya ketika penyuluhan " ho... anak yang sudah disekolahin masih kita urusin sekolahnya juga to".

Remaja juga mulai merasakan ada sedikit perubahan dari orangtua mereka, yaitu sejak mendapatkan penyuluhan orangtua mulai menunjukkan sikap peduli ketika masih pulang larut malam dan mulai memberikan nasihat tentang pentingnya sekolah untuk mengubah nasib di masa yang akan datang. Selain itu remaja putri menyebutkan bahwa orangtua mereka sudah mulai memberikan saran untuk menikah den gan laki-laki yang lulus sekolah supaya kehidupannya di masa mendatang lebih baik. Seperti yang diungkatkan SY "ibu saya masih ingin saya segera menikah tapi beliau ingin saya menikah dengan orang yang sekolah supaya nasibnya lebih baik dikemudian hari".

G uru di SM P muhammadiyah N gloro mengatakan bahwa mereka sudah memahami bahwa perlu komunikasi efektif dengan remaja untuk menyadarkan dan meningkatkan motivasi mereka melanjutkan sekolah, namun terkadang mereka kehabisan cara untuk melakukannya. $\mathrm{H}$ al ini terjadi karena permasalahan yang dialami oleh anak didiknya cukup kompleks, sehingga mereka juga cukup sulit untuk memberikan bantuan sedangkan di sekolah tidak ada guru bimbingan dan konseling yang khusus menangani siswa yang mengalami permasalahan. Bahkan 30\% guru mulai pesimis dan tidak berupaya melakukan apapun untuk membantu anak didiknya melanjutkan sekolah. Setelah diberikan penyuluhan berupa teknik komunikasi efektif dengan remaja, guru mulai men dapatkan insight bahwa selama ini cara mereka berkomunikasi masih belum efektif dalam mendampingi remaja. Guru yang mengikuti penyuluhan ini pun $100 \%$ kembali bersemangat untuk menjalankan peran mereka sebagai motivator untuk anak didiknya melanjutkan pendidikan. 


\section{5}

\section{SIMPULAN}

Program pengabdian masyarakat melalui empowering community psichology dapat menjadi salah satu solusi menyelesaikan permasalahan masyarakat desa $\mathrm{N}$ gloro terkait orientasi masa depan remaja bidang pendidikan. A dapun hasil pengabdian ini adalah (1) terdapat perubahan mind set remaja di desa N gloro khusunya SM P M uhammadiyah $\mathrm{N}$ gloro tentang orientasi masa depan bidang pendidikan sebesar $60 \%$, yaitu mulai menunjukkan minat untuk melanjutkan pendidikan ke jenjang SM A/ SM K dan 10\% mulai menunjukkan minat untuk melanjutkan kejenjang perguruan tinggi. (2) 0 ran gtua mulai menyadari bahwa mereka meiliki peran yang penting dalam mendampingi anaknya merencanakan masa depan dan melanjutkan pendidikan sehingga mulai ada rasa kepedulian terhadap kehidupan pendidkan putra putri mereka. (3) guru mengalami perubahan minset sebesar $70 \%$ terkait peran pentingnya dalam memberikan motivasi kepada aanak didiknya, guru juga mulai menemukan cara baru dalam meningkatkan skill berkomunikasi efektif dengan anak didiknya dalam mendampingi dan memberikan motivasi untuk melanjutkan pendidikan ke jenjang yang lebih tinggi.

\section{UCAPAN TERIMAKASIH}

U capan terimakasih kami sampaikan kepada pihak yang telah terlibat dalam proses pelaksanaan pengabdian ini:

1. U niversitas muhammdiyah melalui Lembaga Pengembangan Pendidikan Penelitian dan pengabdian pada Masyarakat yang telah memberikan support dana untuk terealisasinya Program Pengabdian M syarakat dengan skema PPM -KKN ini.

2. Perangkat desa di desa Ngloro yang telah banyak memberikan bantuan mulai dari pengumpulan data sampai proses intervensi.

3. U capan terimakasih dan penghargaan yang tinggi kepada kepala sekolah dan semua guru-guru beserta siswa yang ada di desa $\mathrm{N}$ gloro, dengan dukungan mereka program pengabdian ini dapat terlaksana.

\section{DAFTAR PUSTAKA}

Agusti, I. (2012). Terapi dengan pendekatan solution fokused pada individu yang mengalami quartileife crisis . Jakarta. Fakultas Psikologi UI Hurlock, Elizabeth B. (1991). Perkembangan Anak. (Terj: Metasari Dan Tjandrasa Dan Muslichah Zarkasih), Jakarta: Erlangga.
Corey, G. (2005). Teori dan Praktek Konseling \& Psikoterapi. Bandung: Refika Aditama.

J ong, D.,\& Berg, I. K. (2008). Family based services: A solution-focused approach. New York : Norton Newsome, S., (2002). The Effectiveness and Utility 
of Solution Focused Brief Therapy (SFBT) with AtRisk J unior High School Students: A

QuasiExperimental Study. Columbus : Ohio State University Press.

O'Connell, B. (2001). Solution-Focused Stress Counselling. London : SAGE Publications.

Asmani, J.M. 2010. Panduan Efektif Bimbingan dan Konseling di Sekolah. Yogyakarta: Diva Press.
Palmer, S. 2010. Konseling dan Psikoterapi. Terjemahan Setiadjid. 2010. Yogyakarta: Pustaka Pelajar.

Prayitno \& Amti, E. 2009. Dasar-dasar Bimbingan dan Konseling. Jakarta: Rineka Cipta.

Rusmana, N. 2009. Bimbingan dan Konseling Kelompok di Sekolah (Metode, Teknik dan Aplikasi). Bandung: Rizqi Press 